\title{
Evaluation of Land Administration Systems
}

\author{
Daniel Steudler, Abbas Rajabifard, and Ian P. Williamson* \\ Department of Geomatics, The University of Melbourne, Victoria 3010, Australia
}

\begin{abstract}
Currently there are no internationally accepted methodologies to evaluate and compare the performance of land administration systems. This is partly because land administration systems are in constant reform, and probably more importantly, they represent societies' different perceptions of land. This paper describes the development of a framework to measure and compare the performance of land administration systems. The research is of particular relevance since it develops a management model which links the operational aspects of land administration with land policy.
\end{abstract}

Keywords: Land administration systems; Cadastre; Benchmarking; Evaluation, Performance Indicators.

\section{The Evolving Context of Land Administration}

Land administration systems, and in particular their central cadastral components are essential elements of countries' national infrastructures (UN-FIG, 1999). The United Nation-Economic Commission for Europe states in their Land Administration Guidelines that "these systems are concerned with the administration of land as a natural resource to ensure its sustainable use and development and are as such concerned with the social, legal, economic and technical framework within which land managers and administrators must operate" (UN-ECE, 1996).

The context, in which land administration systems and the central cadastral component are operating, is increasingly evolving. Not only were traditional cadastral systems slow in responding to the changing needs of society (Dale and McLaughlin, 1988), but also the relationship of humankind to land became more dynamic over the last few decades and particularly the last decade. This evolution is reflected in the resolutions of the successive

\footnotetext{
* Corresponding author. Tel.: +61-3-8344-4431; Fax: +61-3-9347-4128; Email: ianpw @unimelb.edu.au
} 
efforts of the International Federation of Surveyors (FIG): the Statement on the Cadastre (FIG, 1995), the Bogor Declaration (UN-FIG, 1996), Cadastre 2014 (Kaufmann and Steudler, 1998), and the Bathurst Declaration (UN-FIG, 1999). The Bathurst Declaration concludes that sustainable development requires a sound land administration system.

In their paper on cadastral trends, Ting and Williamson (1999) identify different phases in the humankind to land relationship depending on the different rates of development of countries. They established a cumulative model of cadastral developments: (i) land as wealth, (ii) land as commodity, (iii) land as scarce resource, and finally (iv) land as a scarce community resource. They conclude that "each of these phases in the humankind/land relationship elicited a corresponding layer of complexity in the function of cadastral systems from a simple record of ownership and fiscal tool, to a cornerstone of land markets and then increasingly detailed landuse planning"; and that "the world is at different points in the continuum. Many developing countries are only just establishing more formal cadastral records for fiscal and also land market purposes... while ...western nations are rushing to create multi-purpose cadastres that take a community approach to sustainable development issues whilst maintaining private ownership."

Cadastres are evolving into broader land administration systems addressing a diversity of issues, ultimately supporting not only land ownership and land markets, but increasingly also sustainable development.

\section{Components of Land Administration System}

The UN-ECE (1996) defines land administration as "the processes of determining, recording and disseminating information about the tenure, value and use of land when implementing land management policies. It is considered to include land registration, cadastral surveying and mapping, fiscal, legal and multi-purpose cadastres and land information systems."

Dale and McLaughlin (1999) define land administration as "the process of regulating land and property development and the use and conservation of the land, the gathering of revenues from the land through sales, leasing, and taxation, and the resolving of conflicts concerning the ownership and use of the land." Like the UN-ECE, Dale and McLaughlin identify ownership, values, and use as the three key attributes of land (Figure 1). They continue that land administration functions can be divided into four functions: juridical, fiscal, regulatory, and information management. The first three functions are traditionally organised around three sets of organisations while the latter, information management is integral to the other three components" (Figure 2). 


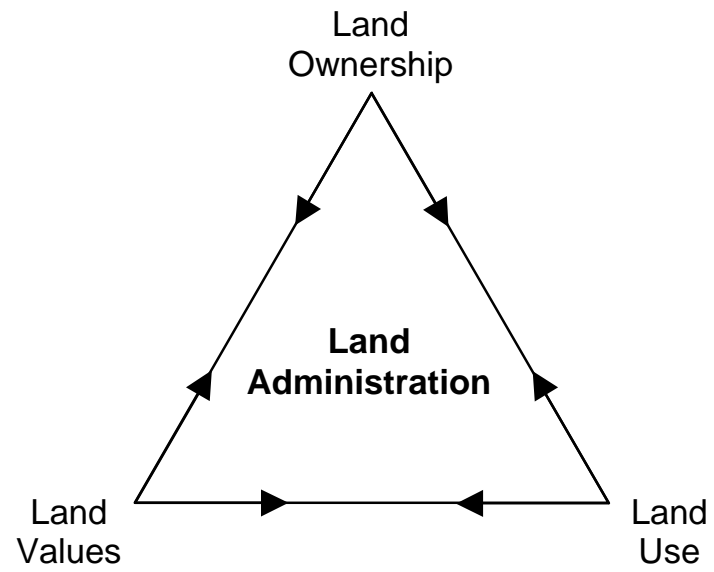

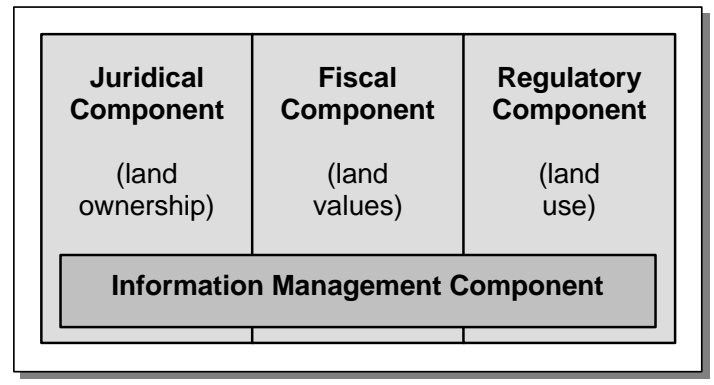

Figure 2: The four basic components of land administration.

Figure 1: The three key attributes of land (Dale and McLaughlin, 1999).

Along with the staggering progress in information technology, the information management function has considerably been developed over the last few decades, with many efforts to establish information systems dealing with land information.

\section{Reasons for Evaluating Land Administration Systems}

Evaluation became a field of interest in the early 1960s in the USA mainly for evaluating development aid projects (Cracknell, 2000). Evaluation is concerned with questions such as: are we doing the right thing, are we doing things right, and what lessons can we learn from the experiences (SDC, 2000).

Evaluating or measuring the performance of a process or a system is a basic prerequisite for improving productivity, efficiency, and performance: "you can't improve what you can't measure" or "if you cannot measure it, you cannot manage it" (Kaplan and Norton, 1996). This perception led in the late 1970's to the concept of benchmarking, when Xerox in 1979 decided to examine its unit costs and to compare them with those of its Japanese competitors. Xerox found that the Japanese competitors sold their products for the same amount that it cost Xerox to just produce them (Evans, 1994). Influenced by Xerox's efforts, Camp (1989) later wrote the text book Benchmarking which became a widely recognized reference as an industry standard for searching for best practices and for establishing benchmarking procedures.

In the land administration field, the coordination and development of reform projects and the evaluation of national land administration systems became more and more of an issue over the last decade. The UN-ECE Meeting of Officials in Land Administration (MOLA) established in 1996 an inventory of aid projects on a European level (unpublished), which revealed that in 
some recipient countries up to 30 projects were simultaneously being sponsored by donor organizations, all having more or less the same goals, but with little or no coordination. One of the reasons for this situation was that there was a general unwillingness in many recipient countries to recognize that for land administration projects, institutional and managerial issues were more critical than technical aspects (Onsrud, 1999). The international understanding of the situation grew over the last few years, and some initiatives were taken to better coordinate cadastral projects.

With a recent "Comparative Study of Land Administration Systems", the World Bank (2003) aims to provide a basis for a more informed assessment of land administration initiatives. The study systematically reviews the characteristics, accessibility, costs, and sustainability of different land titling and registration options based on information compiled in a number of case study countries. The need for a more comprehensive approach in land administration is illustrated by Lavadenz et al. (2002), who observed that:

'...despite the significant resources being invested by the donor community for modernizing land administration infrastructure, there is little systematic discussion of the key elements of such a system and of what constitutes effectiveness within particular socio-economic, cultural and temporal contexts.'

A comprehensive framework for comparing and evaluating land administration system may provide some support to identify such key elements and also for lesson learning. However, the aim of such a framework cannot be to imply similar policy objectives or strategic goals, but to develop a shared methodology for the comprehensive evaluation of land administration systems.

\section{Current Evaluation Methods of Land Administration Systems}

The performance of land administration systems are currently being evaluated by different international organizations, national aid agencies as well as land administration agencies themselves in order to assess the systems for planning, sponsoring, or carrying out reform projects. There is, however, no internationally accepted or standardized method for evaluation; evaluation depends very much on the organization itself that carries out the evaluation, its agenda, its aims, and the commissioned consultants with their professional backgrounds and experiences.

On the international level, there have been few attempts to standardize the procedures for evaluating or comparing land administration systems. This is mainly because the land administration systems are reflecting the cultural and social context of the country in which they 
are operating, making them distinctly different and therefore difficult to compare with each other. In 1997, the FIG-Commission 7 attempted to collect statistical data of national cadastral systems and got feedback from some 50 countries (Steudler et al., 1997). There is a wealth of information, but as the aim was to just make facts transparent, there also was a lack of a clear framework.

Over the last few years, the UN-ECE Working Party on Land Administration (UN-ECE WPLA) tried to coordinate the evaluation of land administration system reforms in transition countries. For reforming and improving these land administration systems, the then chairman of the WPLA, Onsrud (1999) called for lenders, donors and governments "...to coordinate their efforts ..." and that "...the guiding principle for the coordinated approach must be an agreed land administration master plan, which would clarify the ultimate goals, the priorities and the sequence of projects to be implemented, the division of responsibilities between agencies and the cooperation between them." As a result, the UN-ECE WPLA (2001) started to offer assistance to national land administration authorities reviewing the current situation and performance of their land administration system and undertook evaluation missions to countries in transition. The WPLA, however, relied on the background and expertise of the participating consultants and so far did not adopt a standardized method for evaluating and assessing national systems.

Several development agencies adopted a method called "Logic Framework Analysis" (LFA) to investigate and evaluate projects and programs in the field of overseas development. According to Cracknell (2000), the LFA is used by the Canadian International Development Agency (CIDA), the German technical assistance agency (GTZ), the World Bank, and the Swedish International Development Agency (SIDA) among others. It is also used by the Australian development agency (AusAID, 2001).

The first "Logical Framework" was developed for the United States Agency for International Development (USAID) at the end of the 1960's. It is a way of structuring the main elements in a project, highlighting logical linkages between intended inputs, planned activities and expected results (NORAD, 1999). There are many versions of the LFA and considerable variation in terminology, but it basically comprises a simple $4 \times 4$ matrix, which breaks down a project into its component parts, namely, inputs resulting in activities, output, immediate objectives (or project purpose) and wider objectives (or project goal), together with the risks and assumptions involved, and indicators of progress towards the achievement of objectives (Cracknell, 2000). A typical example of a logic framework analysis matrix is presented in Table 1. 
Table 1: Elements of the logic framework analysis matrix (presented in Cracknell, 2000 as a typical example).

\begin{tabular}{|l|l|l|l|l|}
\hline & $\begin{array}{c}\text { Narrative } \\
\text { summaries }\end{array}$ & $\begin{array}{c}\text { Indicators of } \\
\text { progress }\end{array}$ & $\begin{array}{c}\text { Means of } \\
\text { verification }\end{array}$ & $\begin{array}{c}\text { Risks and } \\
\text { assumptions }\end{array}$ \\
\hline Project Goal & & & & \\
\hline Project Purpose & & & & \\
\hline Outputs & & & & \\
\hline Activities & & & & \\
\hline
\end{tabular}

SIDA for example bases its support for projects on national policy criteria and submitted project proposals. Before projects are approved, proposals are to be appraised in accordance with an LFA. As there are not many projects in the land administration field, SIDA has not a standardized framework for appraising land administration projects and rather relies on the professional experience of commissioned consultants, although the LFA is still being used in this context (Österberg, 2001).

In a paper presenting the German approach to cooperation with UN organisations, Zimmermann (2001) points out that "an extended profile for 'Land Administrators' working in international cooperation programs is needed to implement the new land administration paradigm based on good governance, right-based development and sustainability. Advisors in this field should be selected on the basis of the new paradigm which sees them as qualified facilitators of difficult political, institutional, legal and technical processes of change brought about by state reform, macro-economic adjustment and land policy reform." He highlights that the present approaches taken for consulting and evaluating land administration systems are very different and that there is a clear challenge to address this issue.

\section{Development of an Evaluation Framework}

An important decision that has to be taken at the beginning of any evaluation relates to how it will be carried out. For the better understanding, large projects or systems have to be broken down and divided into comprehensible subgroups. In a World Bank seminar about "Public Sector Performance - The Critical Role of Evaluation", Baird (1998) emphasized four elements that are central in how to evaluate the performance of an organization or system. They are:

- well-defined objectives - to know where to go to;

- clear strategy - to know how to get there;

- outcomes and monitorable indicators - to know if on track;

- evaluation of results - to gain input for improvements. 
The first element, the objectives define the targets for the whole system; their evaluation might involve historical and social aspects, the cultural heritage as well as the political, legal, and economic basis. The second element, the strategies define the way forward to reach and satisfy the objectives; the evaluation of the strategies will include the set-up of the institutions and organizations, and the financing structure. The third element, the outcomes are the result of the activities arising from the objectives and strategies and the indicators will give the feedback to evaluate them. The indicators must be monitorable and relevant. The fourth element, the evaluation of the results is the actual process, which takes the outcomes and indicators into account in order to evaluate and review the objectives and strategies. This process has to be done on a regular basis and looks at the performance and reliability of the system as a whole and how the initial objectives and strategies are satisfied.

The four evaluation elements must be thought of as a cyclical process, allowing a regular assessment of the performance on the one hand and a regular review of the initial objectives and strategies on the other. The review cycle can for example be such that the strategies are reviewed annually while the objectives might be reviewed only every four years (Figure 3 ).

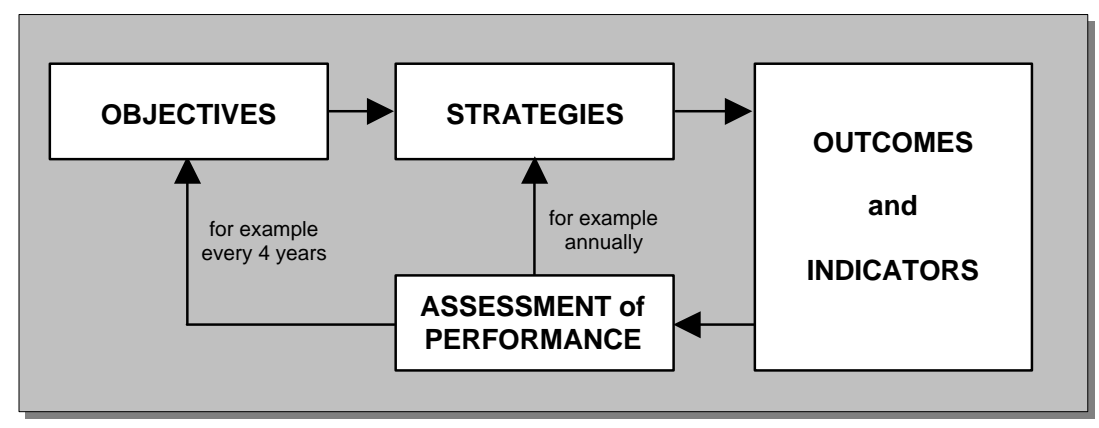

Figure 3: Basic evaluation elements and cycle of assessment (adapted from Selhofer and Steudler, 1998).

In order to fill the elements with content, they have to be brought in context with the relevant stakeholders. For that purpose, the organizational pyramid with the three organizational levels provides a valuable basis. Any organization is structured into different divisions, subdivisions and sometimes also external units, each with separate functions. Regardless of the organization, the three levels of the organizational pyramid can generally be distinguished, representing the different organizational tasks and responsibilities. The three levels are the policy level, the management level, and the operational level.

The organizational levels can be correlated with the evaluation elements mentioned above as well as with distinct groups of people carrying the responsibilities. The policy level can be related with the objectives, of which the government or the executive board is responsible. The management level includes the definition of the strategy, for which the administration or 
management of the organization is responsible. The operations required for the outcomes are handled in the operational level of which the operational units are responsible (Figure 4).

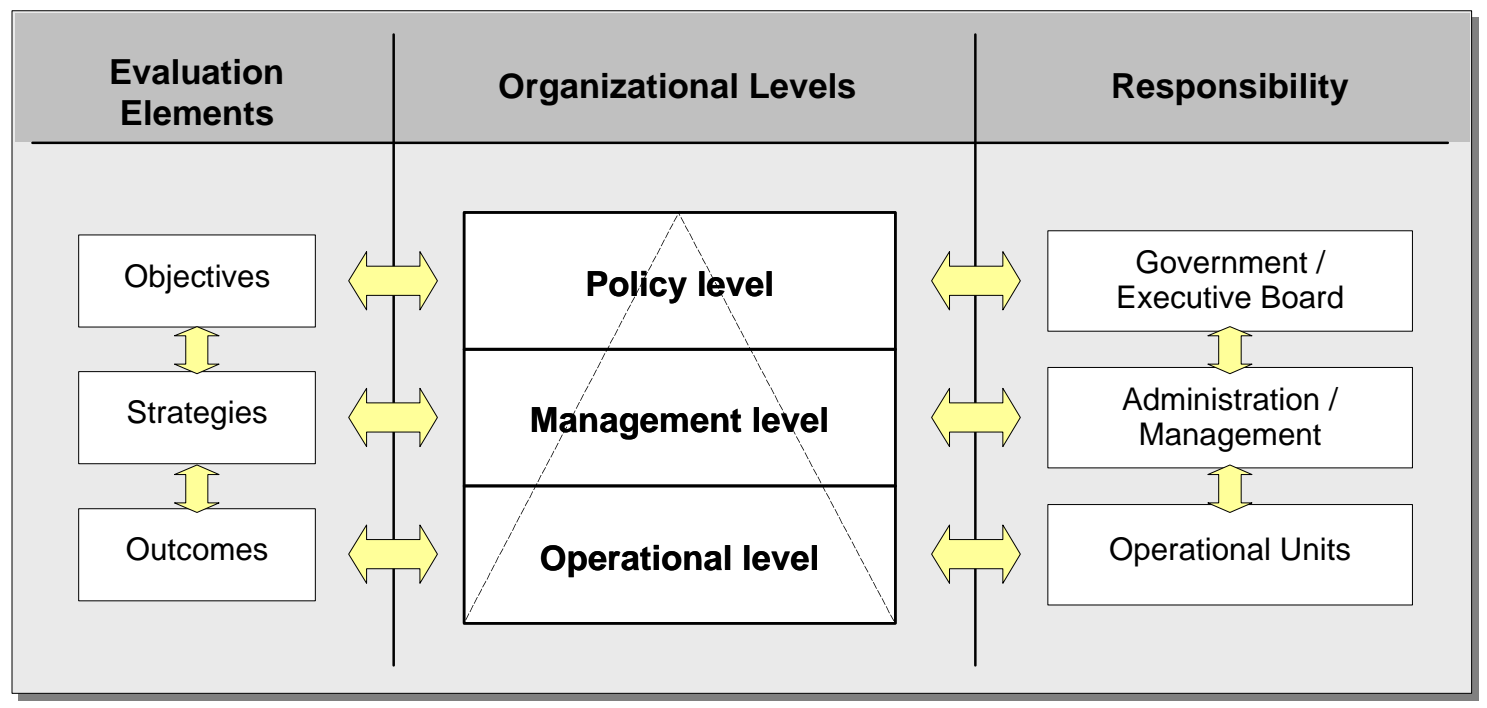

Figure 4: The relation between evaluation elements and organizational levels.

The organizational levels - policy, management, and operational - provide the basis for defining the actual fields or areas of evaluation. For evaluating an administration system as a whole, however, another two areas need to be considered as well. Firstly and according to the evaluation elements discussed above, the "review process", which is looking at how the whole system performs and how objectives and strategies are satisfied. Secondly, there are other "external factors" that have an impact across all three organizational levels. Factors such as human resources, capacity building, or technology all influence the organizational levels in one way or another and need to be addressed. Figure 5 illustrates the evaluation areas together in context.

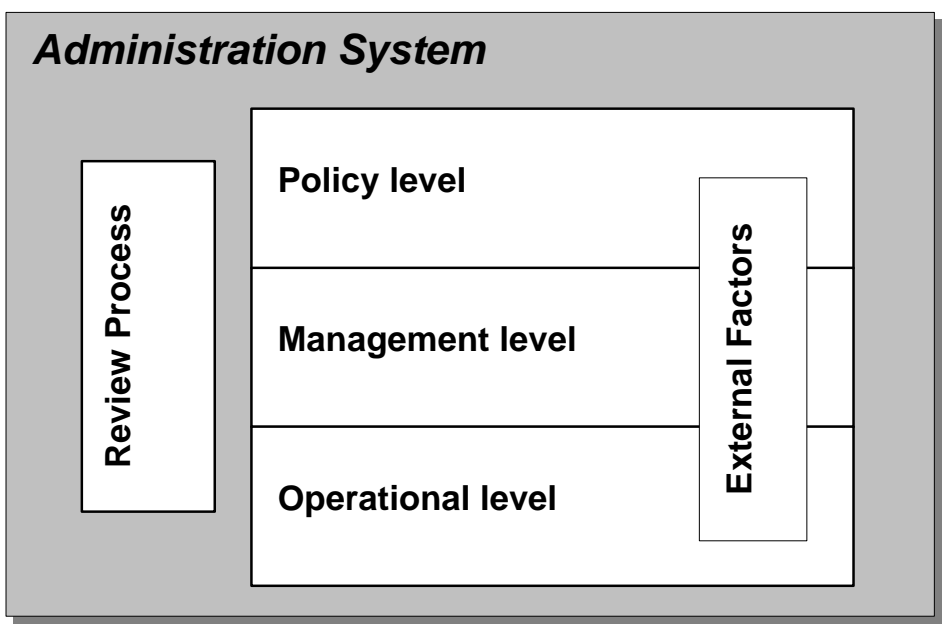

Figure 5: Evaluation areas for evaluating administration systems.

These evaluation areas provide the basis for the evaluation framework in which all areas are evaluated separately, although with a holistic perspective and respecting the overall purpose of the system. For the evaluation, the areas are to be broken down in smaller units again, which are supported by performance indicators, measuring the performance of key variables such as quality, time, and cost in fiscal, social, cultural and environmental terms. The evaluation of 
those areas and indicators can then be done on the basis of predefined "good practice" criteria, which are representing a presumed "ideal" system. The criteria of this ideal system are to be based on the actual objectives and strategies of the system, on the results of previous lessonlearning and comparison projects, or ideally on both.

Table 2 illustrates a generalized evaluation framework where the evaluation areas are further expanded with possible aspects, indicators and good practice criteria.

Table 2: Evaluation framework with possible aspects, indicators and good practice for each area.

\begin{tabular}{|c|c|c|c|}
\hline Evaluation & Possible Aspects & Possible Indicators & Good Practice \\
\hline 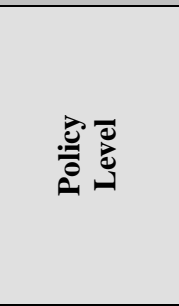 & $\begin{array}{l}\text { objectives and tasks of the } \\
\text { system } \\
\text { - } \\
\text { historic, legal, social, } \\
\text { cultural background } \\
\text { - } \text { equity in social and } \\
\text { economic terms } \\
\text { - } \\
\text { viability of system } \\
\text { (economical, social) } \\
\text { - } \quad .\end{array}$ & $\begin{array}{ll}\text { - } & \text { list of objectives and tasks } \\
\text { - } & \text { historic and legal indicators } \\
\text { - } & \text { social indicators } \\
\text { - economic indicators (expenses, } & \text { incomes, fees, costs) } \\
\text { - } & \text {.. }\end{array}$ & $\begin{array}{l}- \text { system is well defined by objectives and } \\
\text { tasks } \\
\text { - system responds to needs of society } \\
\text { - system is equitable for all } \\
\text { - system is economically viable } \\
\text {... }\end{array}$ \\
\hline 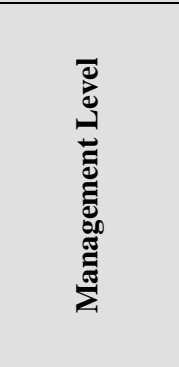 & $\begin{array}{ll} & \text { structural definition of } \\
\text { - } & \text { system } \\
\text { - } & \text { strategic targets } \\
\text { institutional and } \\
\text { organizational arrangements } \\
\text { - } & \text { cooperation and } \\
\text { communication between } \\
\text { institutions } \\
\text { - involvement of private } \\
\text { sector } \\
\text {... }\end{array}$ & $\begin{array}{l}\text { definitions and characteristics } \\
\text { of system } \\
\text { - list of strategic targets } \\
\text { - list of institutions and their } \\
\text { responsibilities and strategies } \\
\text { - links between institutions } \\
\text { (legal, organizational, } \\
\text { technical) } \\
\text { - no. of contracts with private } \\
\text { sector } \\
\text {... }\end{array}$ & 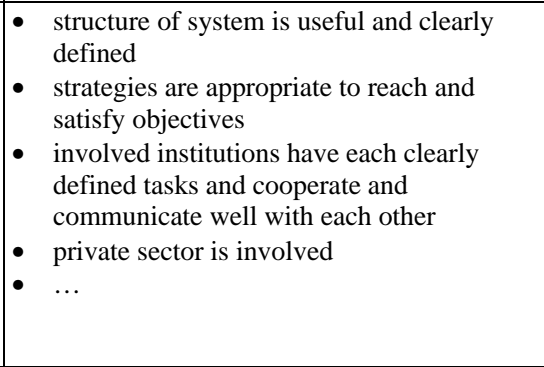 \\
\hline 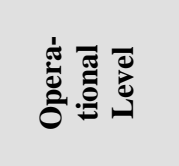 & $\begin{array}{ll}- & \text { outcomes } \\
- & \text { technical specifications } \\
- & \text { implementation } \\
- & \text {-. }\end{array}$ & $\begin{array}{ll}\text { - } & \text { products for clients } \\
\text { - } & \text { technical indicators } \\
\text { - } & \text { implementation factors } \\
\text { - } & \text {. }\end{array}$ & $\begin{array}{l}\text { - } \begin{array}{l}\text { products are appropriate to respond to } \\
\text { objectives }\end{array} \\
\text { - technical specifications and implementation } \\
\text { are appropriate to strategic needs } \\
\text {-.. }\end{array}$ \\
\hline 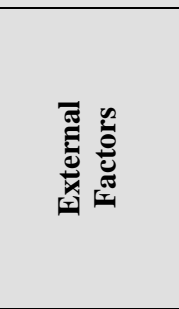 & 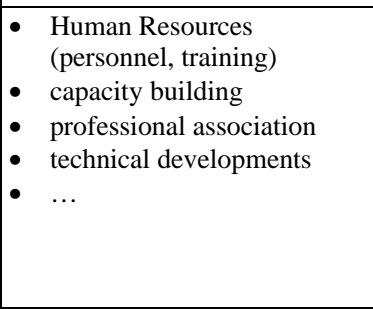 & $\begin{array}{l}\text { - number of personnel, eduction } \\
\text { - continuing eduction (seminars, } \\
\text { etc.) } \\
\text { - no. of universities and students } \\
\text { - is there a professional } \\
\text { association (y/n) } \\
\text { - new technologies on the } \\
\text { market } \\
\text {-.. }\end{array}$ & $\begin{array}{l}\text { appropriate no. of personnel in relation to } \\
\text { task and total population } \\
\text { - continuing eduction on a regular basis } \\
\text { appropriate no. of universities and students } \\
\text { in relation to total population } \\
\text { - } \text { professional association takes an active role } \\
\text { new technologies are evaluated on a } \\
\text { continuing basis } \\
\text {... }\end{array}$ \\
\hline 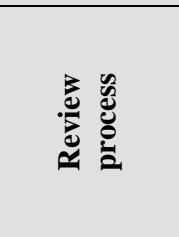 & 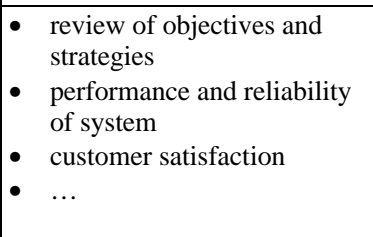 & 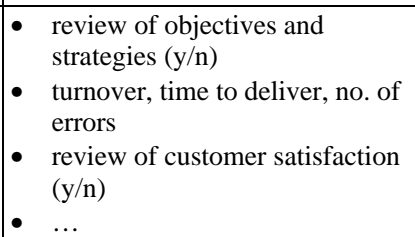 & $\begin{array}{l}\text { - } \text { regular review process } \\
\text { - system is efficient and effective } \\
\text { - system delivers in time and with few errors } \\
\text { appropriate, fast and reliable service to } \\
\text { clients } \\
\text {... }\end{array}$ \\
\hline
\end{tabular}

\section{Application of Evaluation Framework to Land Administration Systems}

The evaluation framework that has been developed in the previous section can be applied to any organization or administration system. It takes a comprehensive approach and considers issues 
such as the different stakeholders in the organisational pyramid, as well as the recurring and regular review of the objectives and strategies through the assessment of the performance.

The cyclical review process supported by benchmarking and feedback corresponds with other accepted concepts in land administration, e.g. the hierarchical framework for re-engineering land administration systems as presented by Williamson and Ting (2001) and illustrated in Figure 6. Global drivers of change are impacting on the whole social system and on the humankind to land relationship. Together with the existing land administration system, these factors provide the input for the development of a conceptual land administration system, which - through an implementation process - is then developed into an operational one. The initial vision and conceptual system will then continually be refined through feedback, benchmarking, and evaluation. This concept corresponds with the above developed evaluation framework.

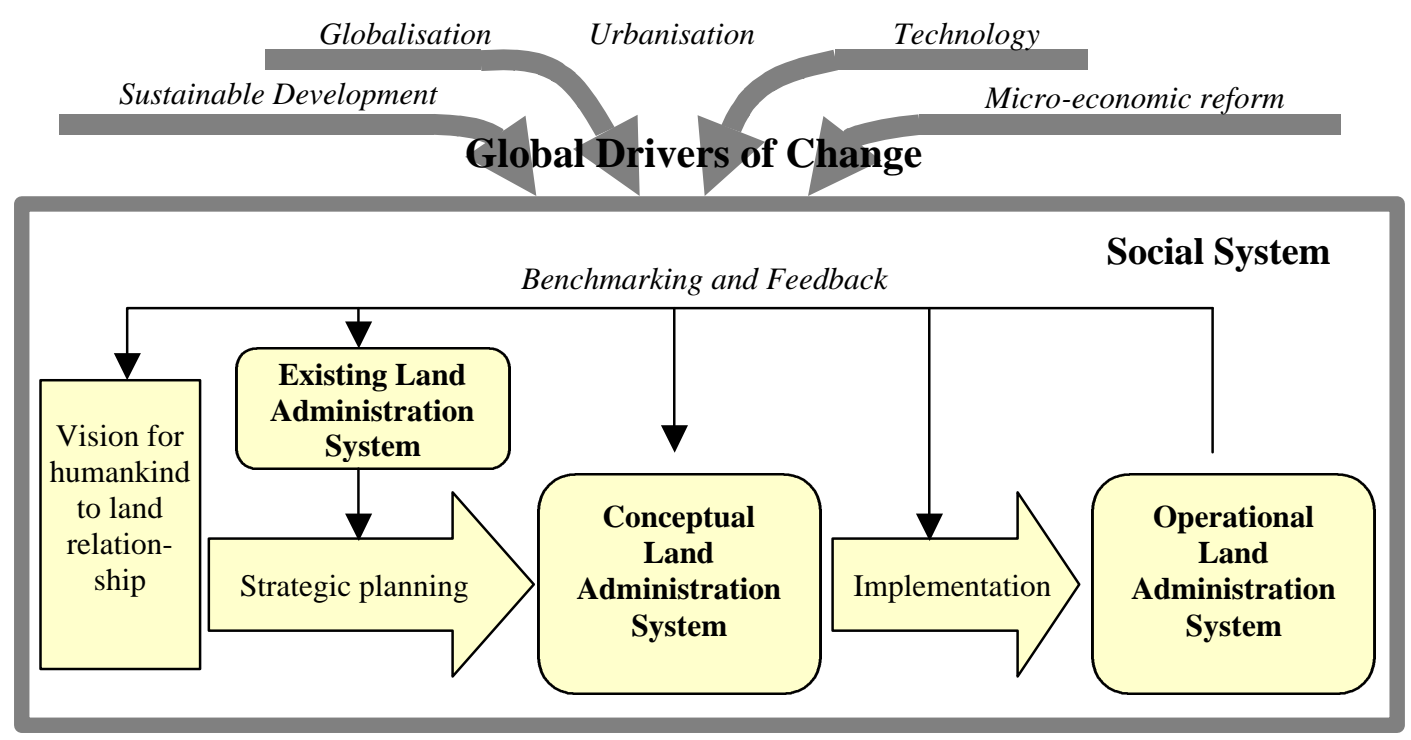

Figure 6: Framework for re-engineering land administration systems (Williamson and Ting, 2001).

Applying the above developed evaluation framework to land administration also corresponds with an approach that has been presented by Kaufmann (2000) at the "1 $1^{\text {st }}$ International Seminar on Cadastral Systems, Land Administration and Sustainable Development" in Bogotá. He introduced a new perspective on cadastres and land administration and makes the analogy that the cadastre - with its traditional role of administering information on rights, restrictions and responsibilities on land - can be considered as sort of a book-keeping or "accounting system" for land issues, ultimately supporting sustainable development. Like the accounting system for an organization or a business, the cadastre has to follow certain rules and principles. For the cadastre, these principles have traditionally been to provide reliable and systematic information 
about individual land parcels, primarily in support of land taxes, land markets, and land-use planning, or as defined earlier for the fiscal, legal, and regulatory functions of land administration.

The analogy also takes the organizational levels from the organizational pyramid into account, whereby the policy level is responsible for the strategic goals and the management level for the resources. In the operational level, the operational tools for the "accounting system" are controlled, providing the sound basis for the whole system. Figure 7 illustrates the analogy of the organizational levels between a general business and land issues, which corresponds with the evaluation framework developed in the previous section.

\begin{tabular}{|c|c|c|c|}
\hline $\begin{array}{l}\text { Organizational } \\
\text { Levels }\end{array}$ & Tasks & General Business & Land Issues \\
\hline $\begin{array}{l}\text { Policy } \\
\text { Level }\end{array}$ & Setting of objectives: & $\begin{array}{l}\text { Sound economic } \\
\text { development }\end{array}$ & Sustainable development \\
\hline $\begin{array}{l}\text { Management } \\
\text { Level }\end{array}$ & $\begin{array}{l}\text { Define strategies and } \\
\text { measures to meet } \\
\text { them: } \\
\text { Define the } \\
\text { administrative } \\
\text { business processes: }\end{array}$ & $\begin{array}{l}\text { Company management } \\
\text { Administrative units and } \\
\text { accounts }\end{array}$ & $\begin{array}{l}\text { Land management, } \\
\text { resource management } \\
\text { Land administration func- } \\
\text { tions and organizations }\end{array}$ \\
\hline $\begin{array}{l}\text { Operational } \\
\text { Level }\end{array}$ & $\begin{array}{l}\text { System and rules for } \\
\text { documenting and } \\
\text { monitoring: }\end{array}$ & $\begin{array}{l}\rightarrow \text { Accounting system - } \\
\text { accepted principles of } \\
\text { bookkeeping: } \\
\text { - reliable } \\
\text { - } \text { complete } \\
\text { - appropriate to needs } \\
\text { adaptable to development }\end{array}$ & $\begin{array}{l}\rightarrow \text { Cadastre - accepted } \\
\text { principles for documentation of } \\
\text { rights, restriction and respon- } \\
\text { sibilities: } \\
\text { - reliable } \\
\text { - systematic, complete } \\
\text { - appropriate to needs and } \\
\text { - laws } \\
\text { - } \quad \text { puaptablic to development }\end{array}$ \\
\hline
\end{tabular}

Figure 7: Cadastre in relation to land management and administration (based on Kaufmann, 2000).

The aspects and possible indicators within the evaluation framework would have to be developed for the case "land administration". We find support for that in a recent paper by Williamson (2001), where he proposes a range of 'best practices' that are useful in undertaking the establishment or re-engineering of land administration systems and that can be considered as the major components of a land administration 'toolbox'. These toolbox principles provide a suitable basis for the evaluation framework as they cover the whole spectrum of land administration. The toolbox principles are: 
- Land policy principles: state and national land policy / roles and responsibilities of the various land-related activities such as land management, land reform, land registration, cadastre and land administration / range of humankind to land relationships / role of land administration system in supporting land market, in managing urban areas, in managing natural resources / recognition of growing complexity of rights, restrictions and responsibilities in relation to land / cost recovery of government services;

- Land tenure principles: formal recognition of appropriate land tenure principles / recognition of indigenous and informal tenures / appropriate responses to circumstances;

- Land administration and cadastral principles: cadastral concept and components of a cadastre / national land information systems / visions for future / implementation of reforms / adequate protection of land rights / trade of those rights: efficient, simple, quick, secure, at low cost;

- Institutional principles: government, ministerial, departmental structures / decentralization and deconcentration / combination of all land administration activities into one government agency / relationships between government and private sector / professional organization;

- Spatial data infrastructure (SDI) principles: role of SDIs in supporting land administration / development of "infrastructure" vs. "business systems" / role of land parcel layer in SDI / hierarchy and dynamic nature of SDI;

- Technical principles: user-driven technical solutions / level of computerization according to country's capacity / technology's provision for overall objectives of system and reform;

- Human resource development and capacity building principles: sustainable longterm capacity of educated and trained personnel to operate the system in both the public and private sectors / capacity building as a mainstream component of a reform project as opposed to add-ons / capacity building is equally applicable to private sector as to public sector.

These toolbox principles provide a valuable basis for establishing the evaluation aspects for land administration and for identifying indicators for each aspect. The aspects and indicators in Table 3 point towards an operational evaluation framework and take the above-developed criteria into account. 
Table 3: Evaluation framework for land administration systems.

\begin{tabular}{|c|c|c|}
\hline Area & Aspects & Possible Indicators (not detailed and not exhaustive) \\
\hline \multirow[t]{3}{*}{ Policy Level } & Land policy principles & $\begin{array}{l}\text { - Existence of a government policy for land administration }(\mathrm{y} / \mathrm{n}) \\
\text { - List of statements for land administration system role } \\
\text { - Existence of independent land board }(\mathrm{y} / \mathrm{n}) \\
\text { - ... }\end{array}$ \\
\hline & Land tenure principles & $\begin{array}{l}\text { - Existence of formal recognition and legal definition of land tenure (y/n) } \\
\text { - Security of tenure (no. and solution of disputes) } \\
\text { - Social and economic equity (underrepresented groups) } \\
\text { - ... }\end{array}$ \\
\hline & Economic and financial factors & $\begin{array}{l}\text { - Cost/benefit and fee structures, land tax revenue } \\
\text { - Economic indicators (value and volume of land market) } \\
\text { - Funding and investment structure } \\
\text { - ... }\end{array}$ \\
\hline \multirow[t]{3}{*}{$\begin{array}{l}\text { Management } \\
\text { Level }\end{array}$} & $\begin{array}{l}\text { Cadastral and land } \\
\text { administration principles }\end{array}$ & $\begin{array}{l}\text { - Adequate protection of land rights } \\
\text { - Support of land market (secure, efficient, simple, at low cost) } \\
\text { - ... }\end{array}$ \\
\hline & Institutional principles & $\begin{array}{l}\text { - List of responsible departments and ministries } \\
\text { - Central or decentral organization } \\
\text { - Number of institutions and offices } \\
\text { - Private sector involvement, no. and volume of contracts } \\
\text { - ... }\end{array}$ \\
\hline & SDI principles & $\begin{array}{l}\text { - Standards arrangements, core data } \\
\text { - Access network, pricing } \\
\text { - Data definition, modelling } \\
\text { - ... }\end{array}$ \\
\hline $\begin{array}{l}\text { Operational } \\
\text { Level }\end{array}$ & Technical principles & $\begin{array}{l}\text { - Data properties (capture method, quality and accuracy) } \\
\text { - Data maintenance, timeliness } \\
\text { - ... }\end{array}$ \\
\hline \multirow[t]{4}{*}{$\begin{array}{l}\text { External } \\
\text { Factors }\end{array}$} & Human resources & $\begin{array}{l}\text { - Number of personnel (public and private) } \\
\text { - Professional association } \\
\text { - ... }\end{array}$ \\
\hline & Capacity building & $\begin{array}{l}\text { - Number of universities and students } \\
\text { - Funding structure for capacity building } \\
\text { - On-going education (no. of workshops, seminars) } \\
\text { - ... }\end{array}$ \\
\hline & Research and development & $\begin{array}{l}\text { - Number of research institutes in the land administration field } \\
\text { - ... }\end{array}$ \\
\hline & Technology & $\begin{array}{l}\text { - Freedom of systems and methods }(\mathrm{y} / \mathrm{n}) \\
\text { - Regular review of new technologies on market and assessment of fitness } \\
\text { for use }(\mathrm{y} / \mathrm{n}) \\
\text { - ... }\end{array}$ \\
\hline $\begin{array}{l}\text { Review } \\
\text { Process }\end{array}$ & Assessment of Performance & $\begin{array}{l}\text { - User satisfaction indicators } \\
\text { - Degree of satisfaction of objectives and strategies } \\
\text { - Existence of a regular review process }(\mathrm{y} / \mathrm{n}) \\
\text { - ... }\end{array}$ \\
\hline
\end{tabular}

\section{Conclusions}

The evaluation of land administration systems is not based on a standardized method that is internationally accepted; the evaluation methods rather depend on the background and experience of the commissioned consultants and the specific project objectives. In consequence, this paper suggests an evaluation framework for land administration systems, which takes a holistic approach looking at the whole system and which considers aspects such as the levels of the organisational pyramid, the regular review of the objectives and strategies, and other external factors having an influence on the system. 
The evaluation framework has been developed by considering four evaluation elements objectives, strategies, outcomes, review process - and by linking them with the different stakeholders within the organisational pyramid. This corresponds with other accepted concepts such as the framework for re-engineering land administration systems and the bookkeeping or accounting system analogy for land administration. The resulting elements, aspects and indicators are then facilitated by the toolbox principles for land administration providing a valuable basis for the evaluation of the whole system.

This paper contributes to the evaluation of land administration systems by considering it as a whole entity; by suggesting evaluating the three organizational levels plus the review process and the external factors; and by proposing the use of the toolbox principles for identifying the aspects and indicators within the evaluation framework. The details of the aspects and indicators, however, are beyond the scope of this paper and need further investigation. The framework nevertheless provides a basis for evaluating land administration systems in a more standardized and comprehensive approach.

\section{Acknowledgements}

The authors wish to gratefully acknowledge Land Victoria and the members of the Centre for Spatial Data Infrastructures and Land Administration at the University of Melbourne for assisting and supporting the preparation of this paper and the associated research. However, the views expressed in the paper are those of the authors and do not necessarily reflect the views of Land Victoria or the University of Melbourne.

\section{References}

AusAID (2001). Project Design Document for the Australian Assistance to the Philippines Land Administration and Management Project, Phase 1, June 2001.

Baird, M. (1998). The Role of Evaluation. In Public Sector Performance - The Critical Role of Evaluation, Selected Proceedings from a World Bank Seminar. Editor Keith Mackay, World Bank Operations Evaluation Department, Evaluation Capacity Development, Washington D.C., April, p. 7-12.

Camp, R.C. (1989). Benchmarking: The Search for Industry Best Practices that Lead to Superior Performance. ISBN 0-87389-058-2, () by ASQC Quality Press.

Cracknell, B.E. (2000). Evaluating Development Aid - Issues, Problems and Solutions. New Delhi, London, SAGE Publications, ISBN 0-7619-94041, 386p.

Dale, P. and McLaughlin, J.D. (1988). Land Information Management. Clarendon Press, Oxford; Oxford University Press New York, ISBN 0198584059, 266 p.

Dale, P. and McLaughlin, J.D. (1999). Land Administration Systems. Oxford University Press, Great Clarendon Street, Oxford OX2 6DP, ISBN 0-19-823390-6, 169 p. 
Evans, A. (1994). Benchmarking - Taking Your Organization Towards Best Practice! The Business Library, Information Australia, 45 Flinders Lane, Melbourne VIC 3000, ISBN 1 86350178 9, () Anne Evans, 234 p.

FIG (1995). Statement on the Cadastre. Report prepared for the International Federation of Surveyors (FIG) by Commission 7, Cadastre and Land Management (<http://www. fig7.org.uk/publications/cadastre/statement_on_cadastre.html>, accessed: 10. Oct. 2002).

Kaplan, R.S. and Norton, D.P. (1996). Balanced Scorecard: Translating Strategy Into Action. Boston, Mass., Harvard Business School Press, 322 p.

Kaufmann, J. (2000). Future Cadastres: The Bookkeeping Systems for Land Administration supporting Sustainable Development. Paper presented at the 1st International Seminar on Cadastral System, Land Administration and Sustainable Development in Bogotá, Colombia, 3-5 May (<http://www.swisstopo.ch/fig-wg71/doc/bogota00/bogota.pdf>, accessed: 10. Oct. 2002).

Kaufmann, J. and Steudler, D. (1998). Cadastre 2014 - A Vision for a Future Cadastral System. Rüdlingen and Bern, Switzerland, July, $51 \mathrm{pp.} \mathrm{(<http://www.swisstopo.ch/fig-wg71/}$ cad2014/>, accessed: 10. Oct. 2002).

Lavadenz, I., Sanjak, J., Barnes, G. and Adlington, G. 2002. Concept Paper and Annexes Comparative Study of Land Administration Systems. Unpublished report, prepared by the World Bank, January (cited in World Bank, 2003).

NORAD (1999). The Logic Framework Approach - Handbook for objectives-oriented planning. NORAD Information Centre, ISBN 82-7548-170-8, <http://www.baltichealth.org/ customers/baltic/lfa/>, accessed: 10. Oct. 2002).

Onsrud, H. (1999). Ensuring Success in Land Administration Projects in Countries in Transition. Paper prepared for the First Session of the UN-ECE Working Party on Land Administration, Geneva, 15-16 November, 8pp. (<http://www.unece.org/env/hs/wpla/s1999/session1.html>, accessed: 14. Oct. 2002).

Österberg (2001). Personal email communications, 31. Oct. and 7. Nov. 2001.

SDC (2000). External Evaluation - Part 1. Working Instruments for planning, evaluation, monitoring and transference into Action (PEMT). Swiss Agency for Development and Cooperation, 30p., June.

Selhofer, K. and Steudler, D. (1998). Swiss Cadastral Surveying and New Public Management. Proceedings of XXI International FIG Congress Brighton 1998, Commission 7, Cadastre and Land Management, Special Session 31, July, pp. 595-604.

Steudler, D., Williamson, I.P., Kaufmann, J. and Grant, D.M. (1997). Benchmarking Cadastral Systems. The Australian Surveyor, September, Vol. 42, No. 3, pp. 87-106 (<http://www. geom.unimelb.edu.au/research/publications/IPW/bnchmrk.html>, accessed: 10. Oct. 2002).

Ting, L. and Williamson, I.P. (1999). Cadastral Trends - A Synthesis. The Australian Surveyor, Vol. 44, No. 1, June, pp. $46-54$ (<http://www.geom.unimelb.edu.au/research/publications/ IPW/CadastralTrendsSynthesis.html>, accessed: 10. Oct. 2002).

UN-ECE (1996). Land Administration Guidelines. Meeting of Officials on Land Administration, UN Economic Commission for Europe. ECE/HBP/96 Sales No. E.96.II.E.7, ISBN 92-1-116644-6, 111 p. (available at <http://www.unece.org/env/hs/ wpla/docs/guidelines/lag.html>, accessed: 8. Oct. 2002)

UN-ECE WPLA (2001). Land Administration Reviews - Note prepared by Mr. P. Creuzer (Germany) in cooperation with the secretariat, HBP/WP.7/2001/6, Geneva 19-20 November, 3 pp. (<http://www.unece.org/env/documents/2001/hbp/wp7/hbp.wp.7.2001. 6.e.pdf $>$, accessed: 10. Oct. 2002).

UN-FIG (1996). Bogor Declaration on Cadastral Reform. Report from United Nations Interregional Meeting of Experts on the Cadastre, Bogor, Indonesia, 18-22 March (<http:// 
www.fig.net/figtree/commission7/reports/events/sing97/sing974.htm>, accessed: 10. Oct. 2002).

UN-FIG (1999). The Bathurst Declaration on Land Administration for Sustainable Development. Report from the UN-FIG Workshop on "Land Tenure and Cadastral Infrastructures for Sustainable Development", Bathurst, NSW, Australia, 18-22 October (<http://www.fig.net/figtree/pub/figpub/pub21/figpub21.htm>, accessed: 8. Oct. 2002).

Williamson, I.P. (2001). Land administration "best practice" providing the infrastructure for land policy implementation. Journal for Land Use Policy, Vol. 18, pp. 297-307 (<http://www.geom.unimelb.edu.au/research/publications/IPW/2_01_ipw_LandAdminBest Practice(JLUP00)2.pdf>, accessed: 10. Oct. 2002).

Williamson, I.P. and Ting, L. (2001). Land administration and cadastral trends - a framework for re-engineering. Computers, Environment and Urban Systems, Vol. 25, pp. 339-366 (<http://www.geom.unimelb.edu.au/research/publications/IPW/LandAdminCadTrends.pdf $>$, accessed 10. Oct. 2002)

World Bank (2003). Comparative Study of Land Administration Systems - Global Synthesis of Critical Issues and Future Challenges. Report prepared by Tony Burns, Chris Grant, Anne-Marie Brits and Kevin Nettle of Land Equity International Pty Ltd under a contract with the World Bank, March, 147 p.

Zimmermann, W. (2001). FIG Co-operation with UN Organisations and other International Agencies - The Approach of the German Agency for Technical Co-operation GTZ. Proceedings to "New Technology for a New Century", Technical Conference during the FIG Working Week, 8-10 May, Seoul, Korea (<http://www.fig.net/figtree/pub/ proceedings/korea/full-papers/plenary2/zimmermann.htm〉, accessed: 10. Oct. 2002). 


\section{University Library}

\section{- M M I E E R VA A gateway to Melbourne's research publications}

Minerva Access is the Institutional Repository of The University of Melbourne

Author/s:

STEUDLER, DANIEL;RAJABIFARD, ABBAS;Williamson, Ian P.

Title:

Evaluation of land administration systems

Date:

2004

Citation:

Steudler, D., Rajabifard, A., \& Williamson, I. P. (2004). Evaluation of land administration systems. Land Use Policy, (21), 371-380.

Publication Status:

Published

Persistent Link:

http://hdl.handle.net/11343/33963 